\title{
UPAYA MENINGKATKAN KETERAMPILAN BERBICARA UNTUK MENGEMUKAKAN PENDAPAT MELALUI METODE DISKUSI PADA SISWA KELAS VI
}

\author{
ASMAH \\ Guru SDN 3 Barejulat, asmahhj@gmail.com
}

INFO ARTIKEL
Riwayat Artikel:
Diterima: $21-02-2018$
Disetujui: $21-03-2018$

Kata Kunci:

Metode Diskusi, Keterampilan Berbicara

\begin{abstract}
ABSTRAK
Abstrak: Dilaksanakan Penelitian Tindakan Kelas dengan tujuan penelitian untuk mendeskripsikan peningkatan keterampilan berbicara untuk mengemukakan pendapat melalui metode diskusi pada siswa kelas VI SDN 3 Barejulat tahun 2015/2016. Metode pengumpulan data : observasi, tugas, dokumentasi, dan tes.

Hasil analisis: kemampuan tinggi sebanyak 12 orang tingkat kemampuan sedang 15 orang dengan IPK 65,51 \% pada kategori sedang. Sedangkan keterampilan berbicara dengan menggunakan metode diskusi dalam mengemukakan pendapat dengan kemampuan tinggi sebanyak 25 orang, tingkat kemampuan sedang dengan jumlah siswa 2 orang dengan persentase $7,48 \%$ dengaqn IPK pada kategori $74,00 \%$ kategori tinggi. Jadi penggunaan metode diskusi meningkatkan keterampilan berbicara siswa kelas VI SDN 3 Barejulat tahun 2015/2016.
\end{abstract}

\begin{abstract}
Classroom Action Research carried out with the aim of research to describe the improvement of speech skills to express opinions through the method of discussion on students of class VI SDN 3 Barejulat year 2015/2016. Methods of data collection: observation, tasks, documentation, and tests. Result of analysis: high ability as many as 12 people medium ability level 15 people with GPA 65,51\% in medium category. While speaking skill by using method of discussion in expressing opinion with high ability counted 25 people, medium ability level with number of student 2 person with percentage of $7,48 \%$ dengaqn GPA in category $74.00 \%$ high category. So the use of discussion method improves the speaking skill of grade 6 students of SDN 3 Barejulat year 2015/2016.
\end{abstract}

\section{A. LATAR BELAKANG}

Keterampilan berbicara merupakan modal utama bagi siswa dalam belajar bahasa indonesia. Senada dengan itu, targian (1983:11) mengatakan bahwa berbicara mempunyai peran sosial yang penting dalam kehidupan siswa. Berbicara merupakan alat komunikasi yang sangat diperlukan siswa dan masyarakat yang berbudaya. Mengingat pentingnya manfaat berbicara, pemerintah menaruh perhatian serius terhadap dunia berbicara dan membaca, sehingga dalam penyampaikan suatu gagasan yang bisa mengembangkan pemikiran dan ide dalam berbicara merupakan sesuatu tujuan yang bisa membangkitkan gairah dalam belajar baik dari tingkat SD, SMP, SMA maupun perguruan tinggi.

Dengan demikian, guru juga dituntut untuk selalu inovatif dan kreatif dalam mengemas strategi dalam metode Pembelajaran Yang Aktif, Kreatif, Epektif Dan Menyenagkan (PAKEM) Strategi pembelajaran disarankan lebih mengutamakan pendekatan houristik dibandingkan dengan pendekatan ekspositorik. Pendekatan houristik merupakan bentuk pembelajaran yang lebih menitikberatkan kepada keaktifan siswa, sedangkan pendekatan espositorik adalah bentuk pembelajaran yang menitik beratkan pada peranan guru dalam penyampaian pesan atau materi (Winata Putra dan Risita,1996;145) solusi semacam ini diharapkan dapat meningkatkan motifasi belajar siswa dan dapat mencapai prestasi belajar yang optimal.

Salah satu metode yang dapat dipakai guru dalam proses pembelajarannya adalah metode diskusi melalui metode ini siswa mampu menyerap dan memberikan pendapat mereka terhadap materi yang dipelajari disekolah. Dikatakan bervariasi karena penerapan dari metode diskusi ini tidak menutup kemungkinan menggunakan metode lain pada saat diskusi berlangsung. Di samping itu bentuk atau model diskusipun dikemas secra bervariasi dengan berbagai model misalnya, Model permainan diskusi, model perlombaan diskusi, model diskusi kelompok, model diskusi individu dan sebagainya.

Berkaitan dengan hal tersebut, melalui penelitian ini akan mencoba melihat keterlibatan siswa, 
khususnya pada anak anak SD, sejauh mana keterlibatan mereka dalam program pemerintah, yakni program melek huruf. Secara umum penelitian ini diharapkan dapat mengungkap keterampilan berbicara dan keterampilan memahami kemampuan siswa dalam memgemukakan suatu pendapat. Dengan demikian, daya serap ilmu pengetahuan oleh para siswa juga dapat diketahui.

Tujuan pendidikan pada dasarnya mengantarkan para siswa menuju pada perubahan-perubahan tingkah laku baik intelektual, moral maupun sosial agar dapat hidup mandiri sebagai individu dan makhluk sosial. Di dalam mencapai hal tersebut siswa beriterakasi dengan lingkungan belajar yang diatur melalui proses pengajaran.

Berdasarkan latar belakang di atas peneliti tertarik untuk meneliti "Upaya Meningkatkan Keterampilan Berbicara Untuk Mengemukakan Pendapat Melalui Metode Diskusi Pada Siswa Kelas VI SDN 3 Barejulat Kecamatan Jonggat Tahun Pelajaran 2015/2016".

\section{B. METODE PENELITIAN}

\section{Setting Penelitian}

Populasi dalam penelitian ini adalah semua siswa kelas VI SDN 3 Barejulat tahun pelajaran 2015/2016, sebanyak 48 orang siswa

\section{Metode Pengumpulan Data}

Metode pengumpulan data merupakan prosedur yang sistematis dan standar untuk memperoleh data yang diperlukan dan selalu terkait dengan masalah penelitian yang ingin dipecahkan. Masalah memberi arah dan mempengaruhi metode pengumpulan data (Nazir, 1983:45). Penjelasan di atas memberi inspirasi betapa penting peranan metode dalam mengumpulkan data dalam sebuah penelitian. Maka, metode yang digunakan dalam penelitian ini adalah metode tes dengan batas pengertian sebagai berikut:

\section{a. Metode Observasi}

Di dalam pengertian psikologis, observasi disebut pula dengan pengamatan, meliputi pemusatan perhatian terhadap suatu objek dengan menggunakan seluruh alat indra. Jadi, mengobservasi dapat dilakukan melalui penglihatan, penciuman, pendengaran, perabaan, dan pengecap.

\section{b. Metode Dokumentasi}

Margono menjelaskan bahwa metode dokumentasi adalah cara mengumpulkan data melalui peninggalan tertulis. Kaitannya dengan penelitian ini adalah mengumpulkan data yang peneliti lakukan melalui sumber teknis, arsip atau catatan tertulis. Data-data tertulis ini sangat penting peranannya selain untuk melengkapi data yang diperoleh melalui pengamatan (observasi) dan wawancara.

\section{c. Metode Tes}

1. Tes adalah suatu alat atau prosedur yang sistematis dan objektif untuk memperoleh data atau keterangan- keterangan yang diinginkan tentang seseorang dengan cara boleh dikatakan tepat dan cepat.

2. Tes merupakan metode pengumpulan data yang sifatnya mengevaluasi hasil proses (pra test dan post test) intrumentnya dapat berupa soal-soal ujian dan soal-soal tes ( Hariwijaya, 2007: 87 ).

\section{d. Metode Analisis Data}

Metode yang digunakan dalam menganalisis data pada penelitian ini adalah metode deskriptif kuantitatif yaitu pendekatan kuantitatif dengan dasar pijakan pada realitas dan kondisi real (defacto) tentang fenomena-fenomena di lapangan. Gejalagejala yang nampak menjadi sumber data dan bahan-bahan serta material yang akan diteliti, yang terkadang tidak selalu relevan dengan asumsi dasar atau gambaran yang digambarkan dan dibangun sebelumnya.

Untuk mengukur kemampuan menentukan jenis kata, maka dalam mendapatkan hasil yang akurat, penulis menganalisis hasil kemampuan anak tersebut dengan menggunakan rumus-rumus sebagai berikut.

1. $\mathrm{SMi}=100$

2. $\mathrm{Mi}=1 / 2 \times \mathrm{SMi}$

3. $\mathrm{SDi}=1 / 3 \times \mathrm{Mi}$

a) Kemampuan Individual

Untuk mengetahui tingkat kemampuan individual dipergunakan norma relatif skala tiga sebagai berikut:

- Kemampuan tinggi $:$ Mi + 1 SDi (ke atas)

- Kemampuan sedang $: \mathrm{Mi} \pm 1$ SDi (di antara)

- Kemampuan rendah : Mi - 1 SDi (ke bawah)

b) Indek Prestasi Kelompok

Indeks prestasi kelompok dapat dihitung dengan membagi nilai rata-rata dengan nilai maksimal yang mungkin dicapai dalam tes, dan kemudian mengalikan hasil bagi ini dengan seratus, atau secara singkat dapat dilihat seperti di bawah ini

$$
I P K=\frac{M}{S M_{i}} \times 100
$$

Lihat Pedoman IPK:

$00-30=$ Sangat kurang

$31-54=$ Kurang

$55-69=$ Normal (sedang)

$70-89=$ Tinggi

$90-100=$ Sangat tinggi 


\section{HASIL DAN PEMBAHASAN}

1. Siklus I

\section{a. Persiapan Pembelajaran}

Dalam pelaksanaan pembelajaran berbicara tanpa menggunakan metode diskusi melalui kegiatan berikut ini :

1) Membuat rencana pembelajaran yang akan digunakan pada saat kegiatan dilakukan.

2) Menyusun tes hasil belajar untuk mengetahui hasil belajar siswa

3) Membuat pedoman penskoran

\section{b. Pelaksanaan Pembelajaran}

Pada kegiatan ini, peneliti melaksanakan kegi atan pembelajaran sesuai dengan rencana pembelajaran yang telah disusun untuk meningkatkan kemampuan berbicara tanpa menggunakan metode diskusi.

Kegiatan pembelajaran dapat dibagi menjadi tiga fase tahap pembukaan atau tahap prainstruksional meliputi kegiatan; (1) Memeriksa kehadiran siswa, (2) memeriksa kesiapan alat dan bahan pelajaran baik alat tulis kelas maupun alat tulis siswa, (3) Menuliskan topik dan tujuan pembelajaran di papan tulis.

Tahap ini kegiatan pembelajaran diawali dengan penjelasan guru tentang konsep dasar tentang pembelajaran berbicara dengan menggunakan metode diskusi, Penanaman konsep ini dilakukan melalui kegiatan Tanya jawab antara guru dan siswa. Dalam hal ini guru menjadi fasilitator didalam pelaksanaan pembelajaran berlangsung.

Sebagai lanjutan tahap di atas guru meminta siswa untuk membuka buku paket bahasa dan sastra Indonesia kelas VI untuk SD. Setelah guru menunggu reaksi dari siswa, jika ada siswa yang menanyakan kegiatan apa yang harus dilakukan, guru memberikan petunjuk secara singkat dan jelas kemudian siswa diminta untuk berdemostrasi pengamatan terhadap sesuatu dengan menggunakan kerangka.

Kegiatan berikutnya adalah diskusi tentang hasil pengamatan berdasarkan kelompok. Pembentukkan kelompok berdasarkan kelas keseluruhannya terdiri dari 4 kelompok yang beranggotakan 5 orang tiap kelompok. Guru memberikan lembaran kertas kepada setiap kelompok untuk menuliskan jawaban. Pada saat proses diskusi berlangsung tugas guru adalah membimbing atau memfasilitasi pelaksanaan diskusi serta memantau dan memperhatikan siswa pada masing-masing kelompok. Guru mencatat kegiatan siswa, siapa saja yang aktif, yang serius dan antusias terhadap tugas yang diberikan. Guru mempersilakan siswa untuk mempertanyakan hal-hal yang dianggap kurang jelas selama dalam mengerjakan soal.

Kegiatan lanjutan dari diskusi kelompok adalah diskusi kelas. Setiap kelompok diskusi diminta untuk menunjukkan seorang juru bicara yang akan mempresentasikan hasil diskusi kelompoknya, kelompok lain menanggapi dan membandingkan pendapat tersebut dengan pendapat kelompoknya atau memberikan pertanyaan dan pemilihan kelompok yang akan presentasi tugasnya dipilih acak oleh guru. Yang menjawab pertanyaan bukan hanya juru bicara tetapi semua siswa yang ada didalam kelompok bersangkutan. Dalam fase ini guru hanya bertugas sebagai fasilitator dan motivator yang mengatur jalan diskusi. Siswa yang memberikan tanggapan atau pertanyaan didata dan dicatat dalam hasil observasi.

Setelah diskusi kelas selesai guru menjawab serta memberikan penguatan terhadap masalahmasalah yang dipertanyakan oleh siswa dalam diskusi tadi, serta memberikan kesempatan kepada siswa untuk mempertanyakan hal-hal yang kurang jelas setelah selesai presentasi oleh setiap kelompok, kelompok diberikan sedikit penghargaan yaitu tepuk tangan.

\section{c. Evaluasi Pembelajaran}

Setelah proses pembelajaran dilaksanakan, maka dilakukan evaluasi yang diberikan kepada siswa dalam berbicara dengan menggunakan metode diskusi dengan memperhatikan partisipasi, motivasi, dan kerja sama.

Untuk tahap evaluasi guru memberikan latihan membuat sebuah kelompok diskusi sesuai dengan menggunakan aspek penilaian, hal ini untuk mengukur kemampuan siswa dalam menguasai materi yang telah diberikan atau tidak.

Berdasarkan tabel di atas bahwa guru belum menggunakan variasi gaya mengajar dalam proses pembelajaran secara bervariasi, sehingga bisa membuat siswa bosan/jenuh dalam mengikuti setiap mata pelajaran atau sangat memudahkan untuk memahami materi yang diajarkan.

Dari hasil evaluasi maka untuk membentuk taraf kemampuan siswa dapat dicari dengan rumus sebagai berikut:

1) Mencari Kemampuan Individual

2) Mencari skor maksimal ideal ( SMi) $=100$

3) Mencari angka rata-rata ideal $(\mathrm{Mi})=1 / 2 \mathrm{X}$ Smi $=1 / 2 \times 100=50$

4) Mencari standar deviasi ideal ( Sdi) $1 / 3 \mathrm{x}$ $\mathrm{Mi}=1 / 3 \times 50=16,67$

5) Membuat Pedoman. :

a) Tinggi $=\mathrm{Mi}+1 \mathrm{SDi}$ ke atas $=50+(1 \mathrm{x}$ $16,67)=66,67 \mathrm{ke}$ atas 
b) Sedang $=\mathrm{Mi} \pm \mathrm{SDi}=50 \pm(1 \times 16,67)=$ 66,67-33,33

c) Rendah $=\mathrm{Mi}-\mathrm{SDi}$ ke bawah $=50$ $(1 \times 16,67)=33,33$ ke bawah.

$$
\text { IPK } \begin{aligned}
\quad=\underline{M} \times 100 \% \\
=\frac{65,51}{100} \times 100 \% \\
=65,51 \%
\end{aligned}
$$

\section{Siklus II}

\section{a. Persiapan Pembelajaran}

Dalam hasil belajar siswa pada siklus II menunjukkan bahwa kemampuan siswa dalam keterampilan berbicara dengan menggunakan metode diskusi masih rendah. Oleh sebab itu, pelaksanaan siklus II, kegiatan pembelajaran lebih ditekankan pada pengembangan kalimat topik dengan memperhatikan segi penguasaan kosa kata, penggunaan kalimat efektif, tanda baca, dan bahasa baku serta keterkaitan antara kalimat topic dengan kalimat pengembang penjelas.

Perencanaan tindakan pada ini hampir sama dengan di atas berbicara tanpa metode diskusi, namun penyusunan perencanaan mengacu pada hasil refleksi siklus I. Persiapan yang dilakukan pada siklus II diantaranya :

1) Membuat rencana pelaksanaan pembelajaran yang efektif dan lebih menyenangkan siswa yang berorientasi pada penguasaan unsur-unsur berbicara secara umum.

2) Menyusun tes hasil belajar dalam bentuk umum untuk mengetahui hasil belajar siswa.

3) Membuat padanan peroskaran

\section{b. Pelaksanaan Pembelajaran}

Dalam pelaksanaan ini diikuti oleh 27 siswa yang terdiri dari 17 siswa laki-laki dan 10 siswa perempuan. Pada awal pembelajaran sebagian siswa memperhatikan penjelasan dari guru, namun ada beberapa siswa yang tidak memperhatikan, akan tetapi pelaksanaan pembelajaran tetap lancar. Pada kegiatan inti siswa sudah mulai paham tentang materi yang diajarkan oleh guru, walaupun ada beberapa siswa yang belum bisa, kemudian pembelajaran dengan metode diskusi ini terdapat beberapa peningkatan dalam proses pembelajaran seperti :

1. Kegiatan Awal
a. Apersepsi

b. Motivasi

2. Kegiatan Inti a. Siswa Memperhatikan penjelasan guru tentang pembelajaran berbicara.

b. Siswa memahami tentang pembelajaran berbicara dengan menggunakan metode diskusi

c. Siswa melengkapi pembelajaran berbicara dengan memperhatikan contoh dalam berbicara

3. Penutup

a. siswa memperbaiki ketepatan, kecepatan, kelancaran dan keberanian dalam berbicara

b. Repleksi

c. Guru dan siswa menyimpulkan isi pembicaraan

\section{c. Evaluasi Pembelajaran}

Hasil evaluasi tentang keterampilan berbicara dengan menggunakan metode diskusi pada siswa kelas VI SDN 3 Barejulat pada siklus II. Berdasarkan hasil analisia data dan perhitungan yang telah diuraikan di atas dapat dilihat bahwa kemampuan siswa dalam keterampilan berbicara menggunakan metode diskusi pada siswa kelas VI SDN 3 Barejulat Tengah Kabupaten Lombok Tengah Tahun Pelajaran 2015/2016 tinggi, sedang, dan rendah. Sehubungan dengan kenyataan tersebut, maka kepada guru kelas VI SDN 3 Barejulat Kecamatan Jonggat, khususnya atau guru-guru SDN termasuk dalam kategori tinggi yaitu 74,00\%.

\section{Persiapan Pembelajaran berbicara tanpa menggunakan metode diskusi}

Persiapan pembelajaran berbicara dapat kita tuangkan dalam analisis data untuk Perencanaan tindakan pada ini hampir sama dengan siklus I, namun penyusunan perencanaan mengacu pada hasil refleksi siklus I. Persiapan yang dilakukan pada diantaranya :

a. Membuat rencana pelaksanaan pembelajaran yang efektif dan lebih menyenangkan siswa yang berorientasi pada penguasaan berbicara secara umum (aspek berbicara).

b. Menyusun tes hasil belajar dalam bentuk umum untuk mengetahui hasil belajar siswa.

c. Membuat padanan peroskaran

4. Persiapan Pembelajaran Berbicara dengan Menggunakan Metode Diskusi

\section{a. Pelakasanaan pembelajaran}

Dalam pembelajaran berbicara tanpa menggunakan metode diskusi dapat kita lihat dari hasil pelaksnaan ini dengan ikuti oleh 27 siswa yang terdiri dari 17 siswa laki-laki dan 10 siswa perempuan. Pada awal pembelajaran sebagian 
siswa memperhatikan penjelasan dari guru, namun ada beberapa siswa yang tidak memperhatikan, akan tetapi pelaksanaan pembelajaran tetap lancar. Pada kegiatan inti siswa sudah mulai paham tentang materi yang diajarkan oleh guru, walaupun ada beberapa siswa yang belum bisa, kemudian pada siklus II ini terdapat beberapa peningkatan dalam proses pembelajaran seperti : kegiatan belajar mengajar berjalan lancar, siswa mau mengajukan pertanyaan dan bergairah mengikuti pembelajaran, serta siswa sudah mampu berbicara dengan metode diskusi melalui objek yang ada.

\section{b. Evaluasi Pembelajaran}

Berdasarkan analisis data dalam hasil siklus I dan siklus II pada Pembelajaran berbicara menggunakan metode diskusi, pada siklus I dapat diperoleh nilai $63,14 \%$ untuk rata-rata pencapaian kelas dan 65,51 \% dari jumlah seluruh siswa yang mendapat nilai standar minimal ke atas. Pada tahap ini terlihat bahwa hasil belajar siswa kurang maksimal sehingga dibutuhkan perbaikan lebih lanjut dan bimbingan khusus. Hal tersebut disebabkan siswa masih kurang bergairah dalam mengikuti pelajaran siswa malu bertanya terhadap materi yang belum dikuasai, siswa kurang aktif di dalam kelas, dan kurangnya kemampuan siswa berbahasa Indonesia yang baik dan benar. Berdasarkan pemantauan tersebut, maka dapat disimpulkan bahwa pada pelaksanaan siklus I, siswa belum mampu menyusun paragraf dengan pengembangan kalimat topik, sehingga hasil yang didapatkan kurang maksimal.

Data hasil penelitian siklus II, dapat diperoleh nilai 79,92 atau $80 \%$ dari rata-rata pencapaian kelas dan $74 \%$ siswa yang memperoleh nilai standar minimal ke atas.

Berdasarkan hasil pelaksanaan siklus II menunjukkan bahwa tingkat kemampuan dalam berbicara walaupun masih terdapat nilai kurang yang diperoleh siswa. Dari hasil tersebut terlihat bahwa pencapaian nilai akhir tujuan pembelajaran mencapai 79,91 \% atau $80 \%$ untuk rata-rata pencapaian kelas $74 \%$ untuk siswa yang memperoleh nilai standar minimal ke atas.

\section{SIMPULAN DAN SARAN}

\section{Simpulan}

Berdasarkan hasil analsis data yang dilakukan maka diperoleh simpulan ternyata kemampuan siswa tergolong kategori tinggi. Indeks Prestasi Kelompok (IPK) didapatkan hasilnya adalah 74,00 \%, dengan demikian simpulan terakhir bahwa tingkat kemampuan siswa dalam Meningkatan Kemampuan Berbicara Bahasa Indonesia dengan Menggunakan Metode Diskusi Pada Siswa Kelas VI SDN Barejulat tahun pelajaran 2015/2016 adalah tinggi.

\section{Saran-saran}

Berikut dikemukakan saran-saran sehubungan dengan Peningkatan Kemampuan Berbicara Bahasa Indonesia dengan Menggunakan Metode Diskusi Pada Siswa Kelas VI SDN 3 Barejulat tahun pelajaran 2015/2016 adalah :

a. Walaupun tingkat siswa dalam meningkatkan berbicara Bahasa Indonesia dengan menggunakan metode diskusi tidak memadai, maka guru hendaknya tetap memperdulikan untuk meningkatkan pemberian pengajaran Bahasa Indonesia.

b. Pemerintah dalam hal ini mengambil kebijakan hendaknya memberikan kesempatan kepada guru-guru secara merata untuk mengikuti penataran.

c. Siswa perlu diberi motifasi yang banyak untuk memperoleh pengajaran Bahasa Indonesia.

d. Pihak guru Bahasa Indonesia hendaknya mampu memitivasi siswanya, dengan adanya motivasi dalam diri siswa tersebut untuk belajar maka tidak sulit bagi guru untuk membina dan membimbing para siswa dalam usaha memperoleh ilmu pengetahuan.

e. Para siswa yang memperoleh nilai yang tinggi diharapkan supaya dapat mempertahankan prestasi yang dicapainya dan kalu bisa ditingkatkan lagi, bagi siswa yang memperoleh nilai sedang diharapkan supaya belajar lebih giat lagi agar prestasinya bisa meningkat dari prestasi sekarang dan lebih-lebih lagi yang memperoleh nilai rendah lebih dipacu untuk berlatih menggunakan Bahasa Indonesia yang sebenar-benarnya.

f. Kepala sekolah selaku pemimpin tertinggi pada SDN 3 Barejulat tahun pelajaran 2015/2016 juga harus mempertahankan peran aktif dalam membimbing, mengarahkan dan mendorong guru bidang studi Bahasa Indonesia untuk mempertahankan kwalitas pengajaran.

\section{UCAPAN TERIMA KASIH}

Dengan penuh rasa hormat, saya ucapkan teimakasih kepada:

1. Kepala Dinas Pendidikan Kabupaten Lombok Tengah yang telah memfasilitasi, mengizinkan penulis untk mengadakan penelitian hingga dapat terlaksana dengan baik.

2. Bapak Pengurus PGRI Kec. Jonggat dan Ketua Gugus yang telah menfasilitasi dalam seminar hasil penelitian Guru-guru Kecamatan Jonggat. 
50 | Paedagoria, Vol. 9, No. 1, April 2018, hal. 45-50

3. Bapak Kepala sekolah yang selalu memberi dukungan sejak awal hingga terlaksananya penelitian ini dengan baik.

4. Rekan-rekan guru yang telah memberi dukungan baik secara moral maupun tindakan langsung dalam pelaksanaan penelitian ini.

\section{DAFTAR RUJUKAN}

[1]. Arikunto, Suharsimi. 1998. Prosedur Penelitian Suatu Pendekatan Praktek. Jakarta: Rineka Cipta.

[2]. Aqip, 2003. Propesionalisme Guru Dalampembelajaran . Surabaya : Insan Cendikiawan

[3]. Belkin ang Graay, 1978. Curriculum, Design For Learning. The Bobs Marril Company, Inc. N. Y

[4]. Djamarah, Syaiful Bachri dan Aswan Zain. 2002. Strategi Belajar Mengajar. Jakarta: Rineka Cipta

[5]. Fajar, 2004. Starategi-Strategi Pembelajaran. Surabaya : Pusat Pendidikan Studi Bahasa Indonesia. Unesa

[6]. Logan, DKK, 1972. Media Instruksional Edukatif. PT. Rineka Cipta. Jakarta

[7]. Moleong, Lexy J. 2002. Metodologi Penelitian Kualitatif. Bandung : CV. Remaja

[8]. Margono, 1997. Keterampilan Dasar Menulis. Jakarta : Moddul PGSD Universitas Terbuka.

[9]. Muhadjir, 2003. Kemampuan Dasar Guru Dalam Proses Belajar Mengajar Pen. Bandung : PT. Remaja Rosda Karya.

[10]. Nazir, Moh. 1983. Metode Penelitian. Jakarta. Ghalia Indonesia

[11]. Nurkancana, dkk. 1986. Evaluasi Pendidikan. Jakarta: Usaha Nasional.

[12]. Poerwadarminta 1989, Kamus Umum Bahasa Indonesia. Jakarta: Balai Pustaka

[13]. Roehman watawidjaya, 1988. Memahami Cerita Rekaan. Jakarta : Pustaka Jaya

[14]. Sardiman, 2001.Interaksi Dan Motivasi Belajar Mengajar. Rajawali Pers: jakarta.

[15]. Slameto, 1995. Belajar Dan Faktor Yang Mempengaruhinya. Jakarta PT Bina Aksara

[16]. Winataputra, 2005. Penelitian Tindakan Kelas. Jakarta : Pusat Penerbitan UT.

[17]. Winataputra dan Rosita, 1996. Implementasi Contextual Teaching and Learning (CTL) dalam Kurikulum Berbasis Kompetensi Mata Pelajaran Geografi SMU/MA, Jurnal Ilmu Pendidikan, Jilid 2 Nomor I Halaman 113. Malang : LPTKK dan ISPI. 